\title{
Bankruptcy Reforms in India - Progress and Challenges Ahead
}

\author{
S Kiran Kumar ${ }^{1}$, Dr.D Kavitha ${ }^{2}$ \\ \{goodguykiran@gmail.com ${ }^{1}$, kavitha@psgim.ac.in ${ }^{2}$ \} \\ Student, PSG Institute of Management, Coimbatore, India ${ }^{1}$,Associate Professor, PSG Institute of \\ Management, Coimbatore, India ${ }^{2}$
}

\begin{abstract}
The introduction of the Insolvency and Bankruptcy Code (IBC) in India in 2016 has been viewed a game-changer for the economy. The Code was enacted with an objective to reduce the growing NPA of banks in the country and also to provide a better resolution mechanism for firms in distress. An effective insolvency regime is one that ensures proper treatment for failed entrepreneurs, prefers restructuring to liquidation, has provisions to distinguish an honest debtor from a fraudulent one, enables time-bound resolution, reduces value erosion and maximizes value to all stakeholders. An evaluation of the effectiveness of IBC 2016 against these features shows that the code has its strengths but is burdened due to inadequate infrastructural requirement, overburdened insolvency professionals and undue judicial delays resulting in deterioration in value of assets.
\end{abstract}

Keywords: Insolvency, Bankruptcy, India, Reforms, IBC 2016, Resolution.

\section{Introduction}

Insolvency is the inability of a person or company to honor outstanding debt obligations as and when they become due. It is a 'financial status' and indicates the inability to pay at the promised date due to financial or economic distress [1]. The person/company may or may not be capable of paying at a later date. Insolvency could be either 'cash-flow insolvency', where the firm does not have enough liquid cash to meet its short-term debt obligations or 'Balance Sheet insolvency' where the value of assets is lower than its liabilities [2, 3]. Bankruptcy refers to the state of being bankrupt and is a 'legal status' where a competent court authorizes debt resolution under the legal system designed by a country to tackle theproblem of insolvency [4]. Though insolvency is a prerequisite for bankruptcy, all insolvencies do not result in bankruptcies.

\section{The role of an Insolvency Law}

Post 'Insolvency' but prior to 'Bankruptcy' there are various options available for a firm to avoid stepping into the legal process. For e.g., the firm may consider increasing income, reducing expenses, raising funds, borrowing or re-negotiating the payment schedule with creditors. However, if none of the above yield desired results, there are three legal solutions 
available to both parties i.e. the creditor and debtor: (i) Debt recovery by creditors- selling property piecemeal or as going concern, (ii) Liquidation of the firm by debtor to settle creditors and (iii) Reorganization / rehabilitation to allow business to continue and revive itself [5]. Though these relief mechanisms are universal, the insolvency regulations may be encapsulated in a single law or may be scattered in several laws depending on the legal framework of the country in which the firm is operating.

An effective insolvency regulation results in easy access of credit to business firms and develops an ecosystem wherein the capacity of creditors to lend money increases and which in turn creates a thriving business activity. The lack of transparent and effective legal framework for debt enforcement shall lead to firms resorting to informal mechanisms such as close links and reputation for access to credit. Thus an effective insolvency system provides a safety back up to the businesses in case of a failure by either providing timely credit or by maximizing the value that can be realized from the assets [6].

Enforcement of an effective insolvency resolution institutionally through a legal mechanism shall greatly enhance economic activity of a country [7]. Insolvency resolution mechanism shall provide necessary support for private firms to succeed as the losses in case of failure of a business can be curtailed well in time. Lack of effective insolvency resolution mechanism shall result in a rat race amongst creditors to get back their dues and shall play a spoil sport in developing a market driven economy in the long run [8].

Insolvency resolution process completes the circle of creditors, debtors and failing businesses. It provides the much-needed counter balance to these failing businesses and ensures the credit system is alive by constant churning of money between creditors and debtors. This kind of mechanism is very much required for economically developing countries like India to attract foreign investment as it reduces the time for liquidation of assets or restructuring of debt. Financial institutions like banks enjoy more financial stability in such kind of environment and can sustain their operations for longer duration [7].

Efficiency and competitiveness of corporate sector is greatly enhanced by having anefficient corporate insolvency regulation as it reduces uncertainty of resolution to a large extent and shall also provide a modicum of discipline amongst promoters. It shall also provide better terms of access to the supply of credit for businesses [9].A balanced insolvency regulation shall encourage entrepreneurship and result in starting of new businesses. This in turn generates employment and provides livelihood to many people. Such a scenario is possible due to increased confidence of the creditors to lend and lesser chances of erosion of capital [10].

An efficient insolvency regime shall productive use of resources by eliminating nonviable firms and better reallocation of assets to viable firms [5]. Such an efficient system shall ensure that weak and corrupt firms are liquidated and capital is transferred to strong and innovative firms. A strong legal procedure for timely resolution of debts shall result in balanced approach of debt recovery by creditors and lesser shocks to the financial system of the country [11].

\section{Scenario in India}


Until a few years ago the insolvency resolution process in India had been strongly criticized for its inefficiency and cumbersomeness [12]. The country had multiple fragmented regulations to deal with insolvency $[13,14]$. These were fraught with deficiencies due to inadequate institutional setup [1] and led to time delays and low recovery rate in the resolution process. Due to the existence of multiple statutes, parallel proceedings were possible by different categories of stakeholders resulting in undue delays [12]. Plethora of acts aimed at resolving debt in a fruitful way could not yield viable results. The Corporate Debtors take undue advantage in the pretext of endless litigation at the cost of gullible creditor. However, globalization and interconnected world, necessitated World Bank to include Insolvency Regulation as a key parameter for grading ease for doing business in a country [15]. Subsequently, the insolvency and Bankruptcy code, 2016 was introduced in 2016. The regulation is aimed at bringing a whole bunch of earlier insolvency regulations under one roof and facilitate debt resolution in a time bound manner.

\section{Framework of IBC 2016}

IBC 2016 provided much need impetus for corporate debt resolution by mandating 270 days for debt resolution which was later revised to 330 days failing which liquidation and sale of assets of debtor shall take place. A sound and efficient adjudicating authority, the 'National Company Law Tribunal' (NCLT) and Appellate tribunal, the 'National Company Law Appellate Tribunal' (NCLAT) were created to address all corporate debt distress is- sues. The information utilities were expected to provide authentic information on financialcapacity of registered users to enable better decisions by adjudicating authorities. An independent Insolvency Professional (IP) was to be nominated to take care of the operations of the stressed company. All these measures were expected to ensure value maximization and reduce the influence of promoters during the insolvency process.

\section{Literature Review}

Corporate insolvency theories emerged predominantly from United States and United Kingdom. Prior research has identified two sets of theories, the first states that the primary objective of insolvency should be wealth maximization of the creditors and is creditor centric. The second theory states that the primary motive of insolvency process is to ensure that equitable justice to all the stake holders involved [16]. A proper design of insolvency regimes is required for ensuring efficient productivity [17]. Studies have reiterated that de- sign of insolvency resolutions should provide adequate measures to reduce cost for exit of companies and provide viable exit routes. Exit of non- viable firms shall ensure better avail- ability of resources to viable firms thereby ensuring better market selection and increasing productivity. Also, an effective insolvency regime should have appropriate measures to pre- vent companies reach a stage of insolvency and should incorporate practical methods for restructuring. Another important feature in the design of insolvency regime is the method of restructuring. Insolvency regimes should support restructuring process of viable firms and should not be biased towards liquidation [5]. Insolvency resolutions should not have stringent restrictions on individual or collective dismissals [17]. Further, mechanism should be provided to sell debtor assets seized as a going concern which shall maximize returns of the creditor. A well-designed voting right structure should be incorporated in the insolvency regime failing which minority 
voting right creditor can stall restructuring process. At the same time requirement of unanimous voting rights from creditors shall weaken the prospect of restructuring [18].

SMEs with low capital should have separate method of resolution. SMEs deserve separate treatment for their debt resolution as they work on lesser capital and complex, lengthy and rigid procedures shall incur high costs. This shall render insolvency process futile. If the design of insolvency regime provides a second chance for an entrepreneur to start all over again after initial failure, then this shall provide him/her a good chance to put to use the lessons learnt from past failure and shall also make them better entrepreneurs [19].

Insolvency framework should maintain a fine balance of including or excluding incumbent management in resolution process. Excluding management may result in hiding of facts andmaking insolvency process complex and this would result in non-viable firms surviving for more duration leading to unproductive use of resources. Court involvement by nominating insolvency professional comes at a cost and should be limited to those cases where it is absolutely necessary. Court involvement is not cost effective for small firms [20].

A homogeneous insolvency regime is difficult due to variance in institutional set up like the capability of enforcement agencies, efficiency of judicial system etc. Each country has to design a regime that suits it best. However, this insolvency regime should ideally adhere to best practices followed internationally to factor in globalization [20]. Early warning tools and preventive restructuring of debts shall go a long way in preventing insolvency process [18].

\section{Discussion - Performance of IBC in India}

\section{Is IBC superior to earlier regimes?}

India had a wide range of laws such as The Provincial Insolvency Act, 1920, The Presidency Towns Insolvency Act, 1909, The Sick Industrial Companies (Special provisions), Act, 1985, the SARFAESI Act, 2002 etc. that were dealing with distressed firms. Some of these laws were criticized for allowing certain groups of creditors/debtors to enjoy certain privileges. Substantial delays due to multiple judicial laws plagued the insolvency regime in the country. The IBC 2016 has helped in consolidating the plethora of laws that were existing in the pre-IBC era and has ensured that interest of all stakeholders is protected. Further, the moratorium imposed under Section 14 of IBC has helped in preserving the corporate debtor's assets from judicial interference from other laws. Of the 4541 CIRP cases admitted until June 2021, 2859 (63\%) have been closed through liquidation, resolution, withdrawal or appeal. These numbers are far higher than the closure of cases under previous regimes. The recovery rate through IBC has also been much higher than under the previous regimes. According to the RBI, the recovery rate was at 46\% during FY 2020.

\section{Does IBC provide time-bound resolution?}

The law has resulted in reducing the time taken for resolution from 1550 days under previous regimes to about 482 for approval of resolution plans and 362 days for liquidation orders (IBBI, 2021). The time taken has a direct impact on the value of assets of the Corporate Debtor. The longer the resolution process, the greater is the value deterioration. The improved timelines have helped in better realization in many cases. 
Despite the phenomenal performance, the IBC has been criticized for not being able to adhere to the time frame provided in the legislation. The initial 180-day timeline was too ambitious and subsequent amendments have extended the same to 330 days. Though liquidations were closer to the timelines, cases that went through resolution have experienced delays in the judicial process resulting in delayed resolution.

Poor human resource in the form of inadequate number of judges, inadequate benches in metropolitan cities, and increase in number of cases being admitted every quarter shows that the overall infrastructure support is dismal. The time-taken is determined from the date when the case is admitted to the NCLT and it excludes time at tribunal. The insufficient number of NCLT courts and special benches has been a major reason for the delays. There are only 16 NCLT courts in the country. These courts are not exclusively for insolvency related issues and hence the cases experience undue delays. Considerable time taken even for admission of the case has been a point of concern for many corporate debtors and creditors.

\section{Role of Insolvency Professionals (IP)}

IPs are vital to the insolvency process. They are the link between the debtor, creditors and the regulatory bodies. The IPs are responsible for the operations of the firm once the resolution process commences. However, as most of the IPs are professionally qualified they may not possess the ability to run the operations of the debtors. Also, in some cases malpractices, negligence and lapses on their part have been reported [21]. In many cases, the IPs lack the cooperation of the debtor in running the entity. Though the IBBI has included mandatory disclosure requirements and code of conduct to ensure that the IPs preserve the integrity of the process. Also, the limited availability of IPs capable of handling large scale bankruptcies has also been a hurdle in the process. In some cases the Corporate Debtors have voiced their concern over the mismanagement of the company by IPs and the resultant loss in business due to their actions. Strengthening of the profession is therefore required to achieve the objectives of the IBC.

\section{Has IBC maximized the value of all Stakeholders involved?}

Maximization of returns to all stake holders takes place when the resolution process takes less time, when restructuring takes place more often than liquidation resulting in safeguarding jobs of employees and all other stake holders involved other than creditors and the process incurs fewer costs to the debtor. The long timelines have been detrimental to the process and have resulted in significant loss in value of assets. The large haircuts in most of the resolutions have also received widespread criticism. For e.g., in the Videocon case, there was a $98 \%$ haircut in the resolution plan submitted by Twin Stars.

A good insolvency regime is one that helps firms to restructure rather than to liquidate. Returns are subdued when a firm goes for liquidation than when it runs as a going concern and hence liquidation should be the last resort. However, in case of IBC maximum casesare being liquidated $(47 \%)$ rather than restructured. The IBBI has however clarified that most of the liquidated cases were those that were pending with the BIFR or defunct. Added to this, in many cases there have been second-thoughts / reluctance by the buyer that has resulted in delays pushing the company into liquidation. 
Higher number of liquidations also suggests that the code is being used more for debt clearance rather than for encouraging entrepreneurship. The number of cases initiated by operational creditors who provide credit on short term are far more than the cases being initiated by corporate debtors. Interestingly, it was corporate debtors who initiated maximum number of cases in the initial phase. This shows that insolvency regime is being extensively used for debt resolution.

\section{Conclusion}

Insolvency and Bankruptcy code 2016 provided the much-needed impetus to the ailing Indian banking sector. It is no doubt far superior to the earlier regimes and has improved the pace at which insolvency cases reach a closure. Challenges however exist in terms of poor human resources and infrastructural requirements resulting in cases piling up at the tribunals. The time taken for admission of the case is far exceeding the stipulated 14 days. Also, the preference for liquidation shows that the code is being used more than a tool for debt recovery rather than restructuring. Government, however, has been proactive in making timely amendments to the code to make it more pragmatic. The success of the code depends on increasing judicial infrastructure and improving the availability and capacity of the insolvency professionals.

\section{References}

[1] R. Sengupta, A. Sharma, S. Thomas (2016). Evolution of the insolvency framework for nonfinancial firms in India. Indira Gandhi Institute of Development Research, Mumbai, WP-2016018, http://www. igidr. ac. in/pdf/publication/WP-2016-018. pdf.

[2] J. E. Margret, Insolvency and tests of insolvency: An analysis of the "balance sheet" and"cashflow" tests, Aust. Account. Rev 12 (2002) 59-72.

[3] M. Shamim, Bankruptcy Laws: a comparative Study of India and USA, J. Manage 6 (2019) 247-252.

[4] K. Porter, The pretend solution: An empirical study of bankruptcy outcomes, Tex. Law Rev 90 (2011) 103-162.

[5] S. Djankov, O. Hart, C. Mcliesh, A. Shleifer, Debt enforcement around the world, J. Polit. Econ 116 (2008) 1105-1149.

[6] J. Armour, A. Menezes, M. Uttamchandani, K. V. Zwieten, How do creditor rights matter for debt finance? A review of empirical evidence, Research Handbook on Secured Financing in Commercial Transactions (2015) 3-25.

[7] S. Hagan, Insolvency Reform and Economic Policy, Conn. J. Int. Law 17 (2001) 63-63.

[8] E. Flashcen, T. Desieno, The Development of Insolvency Law as Part of the Transition from a Centrally Planned to a Market Economy, Int. Lawyer (1992) 667-694.

[9] E. Cirmizi, L. Klapper, M. Uttamchandani, The challenges of bankruptcy reform, World Bank Res. Obs 27 (2012) 185-203.

[10] L. W. Chavis, L. F. Klapper, I. Love, The impact of the business environment on young firm financing, World Bank Economic Review. Oxford Academic (2011).

[11] M. J. White, The Corporate Bankruptcy Decision, J. Econ. Perspect 3 (1989) 129-151.

[12] S. Vig, Insolvency Reforms in India: policy and economic implications, J. Contemp. Issues Bus. Gov 25 (2019) 14-29.

[13] A. Gupta, Insolvency and bankruptcy code, 2016: A paradigm shift within insolvency laws in India, Copenhagen J. Asian Stud 36 (2018) 75-99.

[14] A. Ravi, Indian insolvency regime in practice: An analysis of insolvency and debt recovery proceedings, Econ. Polit. Wkly 50 (2015) 46-53. 
[15] K. Rajoria, Study insolvency and bankruptcy code of India : the past , the present and the future, Int. Bus. Law J (2018) 61-70.

[16] H. Nsubuga, Corporate insolvency and employment protection: a theoretical perspective, Nottingham Insolv. Bus. Law e-Journal 4 (2016).

[17] A. Mcgowan, D. Andrews, Design of insolvency regimes across countries, OECD Econ. Dep. Work. Pap 52 (2018) 1-36.

[18] J. C. Bricongne, M. Demertzis, P. Pontuch, A. Turrini, Macroeconomic Relevance of Insolvency Frame- works in a High-debt Context: An EU Perspective, European Economy Discussion Papers, Directorate General Economic and Financial Affairs (DG ECFIN) (2015).

[19] R. N. Eberhart, C. Eesley, K. Eisenhardt, Failure is an option: Failure barriers and new firm perfor- mance, in: Academy of Management 2012 Annual Meeting, AOM 2012. Academy of ManagementBri- arcliff Manor, Vol. 10510, 2012, pp. 1150-1155.

[20] S. Aiyar, W. Bergthaler, J. Garrido, A. Ilyina, A. Jobst, K. Kang, D. Kovtun, Y. Liu, D. Monaghan,

[21] D. Hake, J. Gupta, An Overview of the Working of Insolvency and Bankruptcy Code, 2016 with reference to Insolvency Professionals, Turkish J. Comput. Math. Educ 12 (2021) 28572872 . 